\title{
Evaluation of the anti-bacterial activity of methanolic extract of Chlorella vulgaris Beyerinck [Beijerinck] with special reference to antioxidant modulation
}

\author{
Biswajita Pradhan, Srimanta Patra, Soumya Ranjan Dash, Rabindra Nayak, Chhandashree Behera and
} Mrutyunjay Jena*

\begin{abstract}
Background: The natural antioxidants from Chlorella have potent therapeutic implication in several diseases. However, the anti-bacterial activity and their molecular mode of action have not been investigated yet. The present study focussed on the assessment of antioxidant potential as well as free radical scavenging activity such as DPPH, hydroxyl radical, hydrogen peroxide, and superoxide anion radical assay of Chlorella vulgaris Beyerinck [Beijerinck] (BUACC25) isolated from marine habitat. Furthermore, the anti-bacterial activity and their molecular mode of action have been evaluated.

Results: In the present study, the preliminary phytochemical screening of methanolic algal extract revealed the presence of alkaloids, glycosides, proteins, terpenoids, saponins, coumarin, phenols, and tannins, which was confirmed by in an UV-visible and FT-IR spectroscopy, indicated the distinct spectral peaks. The methanolic algal extract was found to be rich in phenolic content $\left(45 \pm 0.06 \mathrm{mg} \mathrm{GAE} \mathrm{g}^{-1}\right)$ and flavonoid content $(470 \pm 0.25 \mathrm{mg}$ of RUE $\mathrm{g}^{-1}$ ). Furthermore, the methanolic extract was revealed potent antioxidant scavenging activity to scavenge various free radicals with minimum $I C_{50}$ values of DPPH, hydroxyl, $\mathrm{H}_{2} \mathrm{O}_{2}$, superoxide $2.82 \pm 0.30,2.30 \pm 0.25,3.24 \pm$ 0.32 , and $3.15 \pm 0.02 \mathrm{Mg} \mathrm{ml}^{-1}$ respectively. Furthermore, the methanolic extract of $C$. vulgaris exhibited potent antibacterial activity which was evident with the reduction in cfu $\times 10^{7} / \mathrm{ml}$ and $\%$ of cell viability. Mechanistically, reduction of SOD, CAT, and GSH activity provoked ROS-mediated cell death after drug treatment. Moreover, in combination with norfloxacin and ciprofloxacin, methanolic extract of C. vulgaris demonstrated enhanced antibacterial activity with an evident reduction in cfu/ml and \% of cell viability.

Conclusion: This study advocates that $C$. vulgaris (BUACC25) has promising antioxidant activity owing to the presence of phenolic and flavonoids evidenced by scavenging of DPPH, hydroxyl, $\mathrm{H}_{2} \mathrm{O}_{2}$, and superoxide radicals. In addition to this, it sustained anti-microbial activity against E. coli through modulation of SOD, CAT, and GSH. This study carved a path for uncovering a better therapeutic agent against disease-causing bacterial pathogens.
\end{abstract}

Keywords: Antioxidants, Antimicrobial, Chlorella vulgaris, Drug synergism, ROS

\footnotetext{
* Correspondence: mrutyunjay.jena@gmail.com

Algal Biotechnology and Molecular Systematic Laboratory, Post Graduate Department of Botany, Berhampur University, Bhanja Bihar, Berhampur 760007, India
} 


\section{Statement of novelty}

Methanolic extract of $C$. vulgaris demonstrates enhanced anti-bacterial activity via modulation of antioxidant defense enzymes. The antibiotic synergism with methanolic extract of $C$. vulgaris exerts enhanced antibacterial activity in E. coli.

\section{Background}

The marine environment is rich in biodiversity [1] and promising natural resources of anti-cancer, antioxidant, anti-inflammatory, and antibiotic compounds $[2,3]$. Algae are the most promising sources of proteins, vitamins, omega-3-fatty acids, and antioxidants $[4,5]$. Microalgae are reflected in numerous significant source of bioactive compounds such as antioxidants, carotenoids, phenolic and flavonoids [6]. Although many studies reported that several bioactive compounds from macroalgae and their effects on several free radical diseases [7-10] but antioxidant properties of microalgae and particularly of Chlorella spp. from the marine environment are poorly addressed. Microalgae are also potential candidates to produce a wide range of bioactive compounds under different stress conditions [11] with possible modifications in physiological as well as biochemical pathways to maintain cellular homeostasis [12]. The reactive oxygen species (ROS) and other free radicals generated by normal metabolism and enhance their production under environmental stresses, cause the deleterious effect to organisms [13]. Numerous studies have reported that free radical synthesis occurs due to oxidative stress that leads to cancer [14], early aging, Alzheimer's, Parkinson's [15], and cardiovascular diseases such as atherosclerosis and other harmful diseases [16]. The antioxidants act as free radical scavengers, as they are electrons or hydrogen donors and produce numerous stable intermediate radicals. They also prevent oxyradical formation to avoid oxidative stress [17]. Further, antioxidants at lower concentrations affect to delay the oxidation of oxidizable elements and inhibit further oxidation [17]. The antioxidants from algal sources scavenge the oxygenated free radicals more than the antioxidants of plants and seaweeds [18]. Generally, phenolic compounds are the biologically active secondary metabolites chiefly present in microalgae are also act as a strong antioxidant, which neutralizes the ROS before harmful physiological effects in the cell $[19,20]$. Artificial antioxidants are generally phenolic compounds, cause adverse health effects on human health [21]. Therefore natural antioxidants are potent enough to substitute synthetic antioxidants [22]. The different species of Chlorella isolated from both freshwater and marine habitat have been generally used as single-cell protein (SCP) for nutritional supplements for a long [23]. Furthermore, the bioactive compounds from various Chlorella spp. are mostly used as anti-cancer, anti-aging, anti-inflammation, anti-bacterial, and antifungal agents [24]. Pharmaceutically value-added products, particularly antioxidant compounds (phenolic and flavonoids) from microalgae for commercialization are still in infancy stage to replace the synthetic phenolic and flavonoid compounds available in the current scenario.

Biologically active phytoconstituents from microalgae have proven as potent anti-bacterial, anti-fungal, and anti-viral agents against several disease-causing pathogens owing to their antioxidant and radical scavenging activity. C. vulgaris has been proven as an important source of bioactive compounds with several therapeutic implications [25]. Previously, several reports have demonstrated the presence of bioactive compounds in $C$. vulgaris that act as anti-microbial agents [25]. However, the mechanistic pathways underlying the exhibition of such activity have not been demonstrated yet. Therefore, keeping all the scenarios in mind, the present study was focused to evaluate the phytochemicals constituents, antioxidant potential as well as free radical scavenging activity that contribute towards the anti-bacterial activity. In addition to this, the pathways associated with such activity was investigated in connection with drug synergism for enhanced anti-bacterial efficacy. The findings of this investigation may deliver information of $C$. vulgaris as a potential source of future therapeutic agents for disease-causing microbes and can be represented as a dietary supplement during therapeutic intervention.

\section{Methods}

\section{Reagents and chemicals used}

1,1-Diphenyl-2-picrylhydrazyl (DPPH•), gallic acid, ascorbic acid, rutin, hydrogen peroxide $\left(\mathrm{H}_{2} \mathrm{O}_{2}\right)$, sodium salicylate, ferrous sulfate $\left(\mathrm{FeSo}_{4}\right)$, nicotinamide adenine dinucleotide (NADH), Tris- $\mathrm{HCl}$, nitro blue tetrazolium chloride (NBT), phenazine methosulfate (PMS), sodium phosphate, ammonium molybdate, sodium carbonate $\left(\mathrm{NA}_{2} \mathrm{CO}_{3}\right)$, ferric chloride $\left(\mathrm{FeCl}_{3}\right)$, Folin-Ciocalteu's reagent, ammonia solution $\left(\mathrm{NH}_{3}\right)$, sulfuric acid $\left(\mathrm{H}_{2} \mathrm{SO}_{4}\right)$, hydrochloric acid $(\mathrm{HCl})$, chloroform, Fehling's solutions $\mathrm{A}$ and $\mathrm{B}$, sodium carbonate, aluminum chloride $\left(\mathrm{AlCl}_{3}\right)$, mercury potassium iodide, sodium hydroxide $(\mathrm{NaOH})$, isoamyl alcohol, glacial acetic acid, nitric acid, and methanol were purchased from Sigma-Aldrich, Merck and Himedia.

\section{Sample collection and isolation of algal pure strain}

The samples were collected by phytoplankton net (mesh size $25 \mu \mathrm{m}$ ) from Sonapur on the sea, Ganjam, Odisha $\left(\mathrm{N}^{\prime \prime} 19^{\circ} 09.606^{\prime}\right.$ and $\left.\mathrm{E}^{\prime \prime} 085^{\circ} 12.576^{\prime}\right)$. The unialgal cell was isolated from the collected sample by the microcapillary method and identified as Chlorella vulgaris 
Beyerinck [Beijerinck]. The pure strain Chlorella vulgaris assigned with strain no. BUACC25.

\section{Algal culture and preparation of crude extract} The pure algal strain was grown in $\mathrm{BBM}+$ salt $(\mathrm{NaCl})$ medium for 15 days at $14 \pm 10$ day: night condition under 7.5 w. $\mathrm{m}^{2}$ (flux) light intensity and temperature maintained at $23 \pm 2{ }^{\circ} \mathrm{C}$. Algal biomass was harvested by centrifugation and extracted in methanol. Then, methanolic crude extracts were centrifuged, filtered, and evaporated by rotary evaporator. The $\%$ of the yield of algal crude was calculated [26]. The algal crude extract was stored at $-20{ }^{\circ} \mathrm{C}$ for future analysis.

\section{Qualitative screening of phytochemicals}

The phytochemicals screening of algal crude extracts was carried out by the standard procedures [26-28].

\section{Estimation of total phenol content (TPC)}

The total phenolic content was determined by the Folin-Ciocalteu method $[29,30]$ with little modification as described in our previous report (OD; $765 \mathrm{~nm}$ taking gallic acid as standard) [26]. The results were interpreted after three individual experiments and TPC content in the extract was expressed in milligram gallic acid equivalent dry weight ( $\mathrm{mg} \mathrm{GAE} \mathrm{g}^{-1} \mathrm{DW}$ ) of the sample.

\section{Estimation of total flavonoid content (TFC)}

The total flavonoid content of the algal crude extract was estimated by the spectrophotometric method (OD; 415 $\mathrm{nm}$ taking rutin as standard) [31]. The TFC in the extract was expressed in terms of milligram rutin equivalent dry weight ( $m g$ RUE $\mathrm{g}^{-1} \mathrm{DW}$ ) of the algal sample.

\section{Free radical scavenging assay}

The total antioxidant activity was determined by the phosphomolybdenum method [32] with minor modifications as described in our previous report (OD; $695 \mathrm{~nm}$ taking ascorbic acid as standard) [26, 33]. The standard curve calibration was plotted by taking ascorbic acid $\left(10-500 \mu \mathrm{g} \mathrm{ml}^{-1}\right)$ as the positive control. The total antioxidant activity was expressed as the number of gram equivalent of ascorbic acid.

$\mathrm{DPPH}$ free radical scavenging activity of the algal crude extract was determined according to our previous report (OD; $517 \mathrm{~nm}$ taking ascorbic acid as standard) [26] and the percentage of DPPH decolorization of the extract was calculated using the following formula:

$$
\% \text { of decolorization }=\frac{\text { Abs of control }- \text { Abs of sample }}{\text { Abs of control }} \times 100
$$

Hydrogen peroxide radical scavenging activity of the algal extract was estimated by following detailed protocol (OD; $230 \mathrm{~nm}$ taking ascorbic acid as standard) $[29,34]$. Ascorbic acid was used as a positive control to plot the standard curve.

Hydroxyl radical scavenging activity of the algal extracts was estimated by following our previous method (OD; $562 \mathrm{~nm}$ taking ascorbic acid as standard) [29] taking ascorbic acid as standard and the percentage of scavenging effect was calculated by using the following formula:

$$
\text { \%scavenging inhibition }=\left\{1-\frac{\mathrm{A}_{1}-\mathrm{A}_{2}}{\mathrm{~A}_{0}} \times 100\right\}
$$

Where $A_{0}=$ absorbance of the control (without extract), $A_{1}=$ absorbance in the presence of the extract with sodium salicylate and $A_{2}=$ the absorbance without sodium salicylate.

Superoxide anion radical scavenging activity assay was determined based on the reduction of NBT in the presence of NADH and PMS under aerobic conditions (OD; $560 \mathrm{~nm}$ taking ascorbic acid as standard) [35]. Ascorbic acid was used as a standard. The experiment was carried out as per the protocol described in our previous study [29].

\section{UV-visible spectroscopic spectral analysis}

The UV-visible spectroscopic spectrum scan range was 200 to $800 \mathrm{~nm}$ on a UV-visible spectrophotometer to check the presence of phytochemicals compounds in the crude extracts, and spectral peaks were analyzed by comparing the spectrum.

\section{FT-IR spectroscopic spectral analysis}

The presence of various active phytochemicals present in the algal crude extract was crossed checked by FT-IR spectroscopy. The scanning of spectra of FT-IR was fixed within the signal region 4000 to $400 \mathrm{~cm}^{-1}$ of 32 scans with 4.0 resolutions. The functional group of compounds with reference to obtained spectra were determined.

\section{Isolation, culture, and maintenance of bacterial strain}

The pathogenic clinical strain of $E$. coli was isolated from the liquid medical waste by subsequent serial dilution followed by streaking on agar plate [36]. The bacterial strain was cultured in Luria Broth (LB) for further experiments. The strain was maintained in $50 \%$ sterile glycerol under $-20{ }^{\circ} \mathrm{C}$ for further use.

\section{Colony-forming unit count and determination of cell viability}

To determine the $\mathrm{cfu} / \mathrm{ml}, 3 \mathrm{ml}$ of LB was taken in different test tubes containing $100 \mu \mathrm{l}$ of bacterial culture 
attained the exponential phase of growth. 50, 250, and $500 \mu \mathrm{g} / \mathrm{ml}$ of methanolic extract of C. vulgaris were added. The test tubes were incubated for $18 \mathrm{~h}$, and the absorbance was taken at $600 \mathrm{~nm}$ taking the drug in culture medium as blank [37, 38].

\section{Determination of antioxidant enzymes of cultured bacterial strain}

The bacterial protein was isolated as per the method described previously [39]. The bacterial SOD was estimated spectrophotometrically as per the method described by Scott et al. [40]. Similarly, for the determination of CAT activity, the previous method was described by Schwartz et al. [41]. The GSH activity was determined with little modification to Prins and Loos as described by Scott et al. [40].

\section{Statistical analysis}

Experiments were done by taking each sample in triplicate and results were expressed as mean \pm standard deviation (SD). The $\mathrm{IC}_{50}$ value of phenolic content with antioxidant activity was calculated through linear regression and also linear regression coefficient $\left(R^{2}\right)$. All the experiments were repeated in triplicate and the experimental data were analyzed by one-way analysis of variance (ANOVA) represented as values \pm SD. The $p$ value; * $p \leq 0.05$ and $\$$ was compared with the drug were considered as significant.

\section{Results}

Evaluation of active phytoconstituents in methanolic extract of $C$. vulgaris for effective antioxidant activity After the methanolic extraction, the percentage of the yield of Chlorella vulgaris was calculated to be $4.93 \%$. The phytochemical screening was done to screen bioactive compounds that were subsequently important for potent antioxidant activity. Phytochemical analysis of the crude extract of $C$. vulgaris was investigated. The results exhibited the presence of bioactive compounds and associated groups present (Table 1). The UV-visible spectral analysis revealed the presence of phenolic bioactive compounds and FT-IR spectral analysis informed the presence of functional groups and the bonding pattern of the compounds. Hence, the methanolic crude extracts were crossed checked by UV-visible and FT-IR spectral analysis. The UV-visible spectral peak value between 230290, 300-360, and 234-676 nm have exhibited the presence of flavonoids and phenolic compounds in crude extract shown in Fig. 1a. Furthermore, the FT-IR spectroscopic spectral peaks were attributed to the presence of functional groups and bonding patterns in the compound. The characteristic wavenumbers of specific functional groups detected were shown in Fig. 1b. The chemical bonding pattern and functional groups present
Table 1 Phytochemical screening for bioactive compounds of methanol extract of $C$. vulgaris

\begin{tabular}{lll}
\hline Bioactive compounds & Test & Present/absent \\
\hline Alkaloids & Mayer's test & + \\
Glycosides & Keller-kiliani test & + \\
Reducing sugar & Fehling's test & - \\
Proteins & Xanthoproteic test & + \\
Terpenoids & Salkowski's test & + \\
Phenol and tannins & Ferric chloride test & + \\
Steroids & Salkowski's test & - \\
Saponin & Foam test & + \\
Anthocyanin & Hydrochloride test & - \\
Coumarin & Sodium hydroxide test & + \\
\hline
\end{tabular}

in the crude extract of $C$. vulgaris through spectral peak analysis were analyzed and represented (Table 2).

\section{Methanolic extract of C. vulgaris exhibits potent in vitro radical scavenging activity}

Phenolics and flavonoids play a very crucial role in antioxidant activity. The presence of TPC in the crude extract was measured by Folin-Ciocalteu's reagent and was represented in terms of gallic acid equivalent $\left(R^{2}=\right.$ $0.9815)$. The value was estimated to be $45 \pm 0.06 \mathrm{mg} \mathrm{g}^{-1}$ DW. Further, the TFC content algal crude extract was estimated and expressed in terms of rutin equivalent $\left(R^{2}\right.$ $=0.9904)$. The concentration of flavonoid was found to be $470 \pm 0.25 \mathrm{mg} \mathrm{g}^{-1} \mathrm{DW}$. The correlation between TPC and antioxidant activity was further estimated. High correlations between TPC and antioxidant scavenging capacity $\left(\mathrm{DPPH}, R^{2}=0.8191\right.$; hydroxyl radicals, $R^{2}$ $=0.8081$ ) was observed (Fig. 2a). By comparing the correlation coefficients $\left(R^{2}=0.9815\right)$, it was determined that phenolic groups were extremely responsible for antioxidant activity.

The total antioxidant activity was estimated by phosphomolybdenum assay and the results were estimated in terms of mg AAE g ${ }^{-1}$ and to be $411 \pm 0.39 \mathrm{mg} \mathrm{AAE} \mathrm{g}^{-1}$ (Table 3). The quantification of DPPH exhibited a concentration-dependent increase in radical scavenging capacity. The DPPH antioxidant scavenging activities of algal crude extract at various concentrations (10 to 500 $\mu \mathrm{g} \mathrm{ml}^{-1}$ ) were calculated against the standard ascorbic acid concentrations. The crude extracts results displayed $90.48 \%$ of inhibition of antioxidant radical scavenging activities against the standard ascorbic acid $89.68 \%$ at concentrations of $500 \mu \mathrm{g} \mathrm{ml}{ }^{-1}$ (Fig. 2b). The $\mathrm{IC}_{50}$ value of DPPH radical scavenging activity of algal crude extract and ascorbic acid were $2.82 \pm 0.30 \mu \mathrm{g} \mathrm{ml}^{-1}$ and $\left(2.68 \pm 0.29 \mu \mathrm{g} \mathrm{ml}^{-1}\right)$ respectively (Table 4). The $\mathrm{OH}$ scavenging activities of crude extract exhibited a similar inclination in a concentration-dependent manner as 

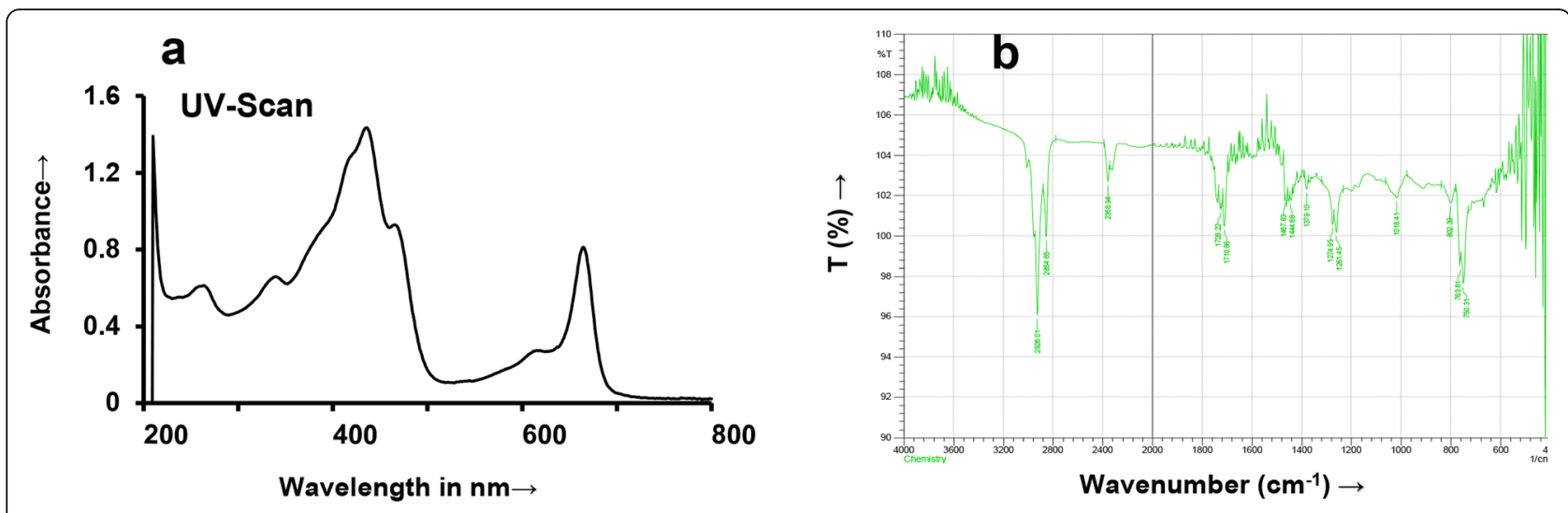

Fig. 1 UV-visible spectrum of methanol extract of C. vulgaris (a), FT-IR results from methanol extract of C. vulgaris (b)

compared to the standard ascorbic acid, and it was displayed the highest level of inhibition, i.e., $90.43 \%$ in the crude extract and $91.85 \%$ in ascorbic acid respectively at $500 \mu \mathrm{g} \mathrm{ml}^{-1}$ concentrations (Fig. 2c). The extract exhibited an increase in hydroxyl radical scavenging properties with $\mathrm{IC}_{50}$ value $\left(2.30 \pm 0.25 \mu \mathrm{g} \mathrm{ml}{ }^{-1}\right)$ over the ascorbic acid $1.87 \pm 0.16 \mu \mathrm{g} \mathrm{ml}^{-1}$ (Table 4). The superoxide radical scavenging activity was quantified to know the potency of the extracts to reduce the NBT. On the other hand, the superoxide scavenging activity also exhibited a similar pattern at $10-500 \mu \mathrm{g} \mathrm{ml}^{-1}$ of crude extract. The result exhibited a concentration-dependent scavenging activity of the crude extract. The inhibition value of crude extract was showed maximum (89.12\%) as compared to standard ascorbic acid was showed maximum (89.47\%) (Fig. 2d) and $\mathrm{IC}_{50}$ value $3.15 \pm 0.02 \mu \mathrm{g} \mathrm{ml}^{-1}$ compared to ascorbic acid $3.22 \pm 0.03 \mu \mathrm{g} \mathrm{ml}^{-1}$ (Table 4). Furthermore, The $\mathrm{H}_{2} \mathrm{O}_{2}$ scavenging activity of the crude extract was investigated, and the results displayed a

Table 2 FT-IR spectroscopy of methanol extract of C. vulgaris

\begin{tabular}{lll}
\hline Peak values & Functional group & Bonding pattern \\
\hline 2926.01 & Amine salts & $\mathrm{N}-\mathrm{H}$ \\
2854.65 & Amine salts & $\mathrm{N}-\mathrm{H}$ \\
2358.94 & Carbon dioxide & $\mathrm{O}=\mathrm{C}=\mathrm{O}$ \\
1728.22 & Aldehyde & $\mathrm{C}=\mathrm{O}$ stretching \\
1710.86 & Aliphatic ketone & $\mathrm{C}=\mathrm{O}$ stretching \\
1467.83 & Alkene methylene group & $\mathrm{C}-\mathrm{H}$ bending \\
1444.68 & Alkene methyl group & $\mathrm{C}-\mathrm{H}$ bending \\
1379.10 & phenol & $\mathrm{O}-\mathrm{H}$ bending \\
1274.94 & Aromatic ester & $\mathrm{C}-\mathrm{O}$ stretching \\
1261.45 & Alkyl aryl ether & $\mathrm{C}-\mathrm{O}$ stretching \\
1018.41 & Sulphoxide & $\mathrm{S}=\mathrm{O}$ \\
802.39 & Alkene & $\mathrm{C}=\mathrm{C}$ bending \\
763.91 & Halo compound & $\mathrm{C}-\mathrm{Cl}$ stretching \\
750.31 & Mono-substituted & $\mathrm{C}-\mathrm{H}$ bending \\
\hline
\end{tabular}

concentration-dependent increase in radical scavenging activity and the standard ascorbic acid was calculated to be $9.73 \%$ to $75.97 \%$ and $11.39 \%$ to $90.23 \%$ respectively at 10 to $500 \mu \mathrm{g} \mathrm{ml}^{-1}$ concentration (Fig. 2e). The $\mathrm{IC}_{50}$ value of $\mathrm{H}_{2} \mathrm{O}_{2}$ radical scavenging activity of crude extract and standard ascorbic acid showed $3.24 \pm 0.32 \mu \mathrm{g} \mathrm{ml}^{-1}$ and $3.21 \pm$ $0.38 \mu \mathrm{g} \mathrm{ml}^{-1}$ (Table 4). These results indicated that the methanolic algal extract exhibited a strong superoxide radical scavenging potency as compared to the standard ascorbic acid. The extract displayed higher hydroxyl and DPPH radical scavenging activity than other radical scavenging assays with $\mathrm{IC}_{50}$ values $2.30 \pm 0.25$ and $2.82 \pm 0.30 \mu \mathrm{g} \mathrm{ml}^{-1}$ (Table 4).

\section{Methanolic extract of $C$. vulgaris mediates anti-bacterial activity against $E$. coli through downregulation of antioxidant enzymes}

The anti-bacterial activity of methanolic extract of $C$. vulgaris was determined against $E$. coli. With increase in drug concentration of methanolic extract of $C$. vulgaris, a reduced $\mathrm{cfu} / \mathrm{ml}$ was observed with values estimated (control $15.0 \times 10^{7}, 50 \mu \mathrm{g} / \mathrm{ml}: 11.575 \times 10^{7}, 250 \mu \mathrm{g} / \mathrm{ml}$ : $\left.9.868 \times 10^{7}, 500 \mu \mathrm{g} / \mathrm{ml}: 7.744 \times 10^{7}\right)$ (Fig. 3a). Further, we evaluated the bacterial cell viability upon drug treatment and observed a reduction in cell viability with an increase in drug concentration. The \% of cell viability was estimated to be $51.63 \%$ at $500 \mu \mathrm{g} / \mathrm{ml}$ (Fig. 3b). Furthermore, to delineate the effective role of antioxidant enzymes for bacterial cell viability, we evaluated the SOD, CAT and GSH activity. Post-drug treatment a subsequent decrease in SOD activity was observed with values (control: 13.9, $50 \mu \mathrm{g} / \mathrm{ml}:$ 9.78, $250 \mu \mathrm{g} / \mathrm{ml}:$ 7.5, 500 $\mu \mathrm{g} / \mathrm{ml}$ : 5.78 ) represented in units/mg protein (Fig. 3c). A similar reduction in CAT activity was also evident with values (control: 15.0, $50 \mu \mathrm{g} / \mathrm{ml}: 11.49,250 \mu \mathrm{g} / \mathrm{ml}: 9.8$, $500 \mu \mathrm{g} / \mathrm{ml}:$ 7.1) represented in units $/ \mathrm{mg}$ protein (Fig. 3d). Moreover, a similar reduction in GSH activity was observed upon drug treatment with values (control: 5.8, 

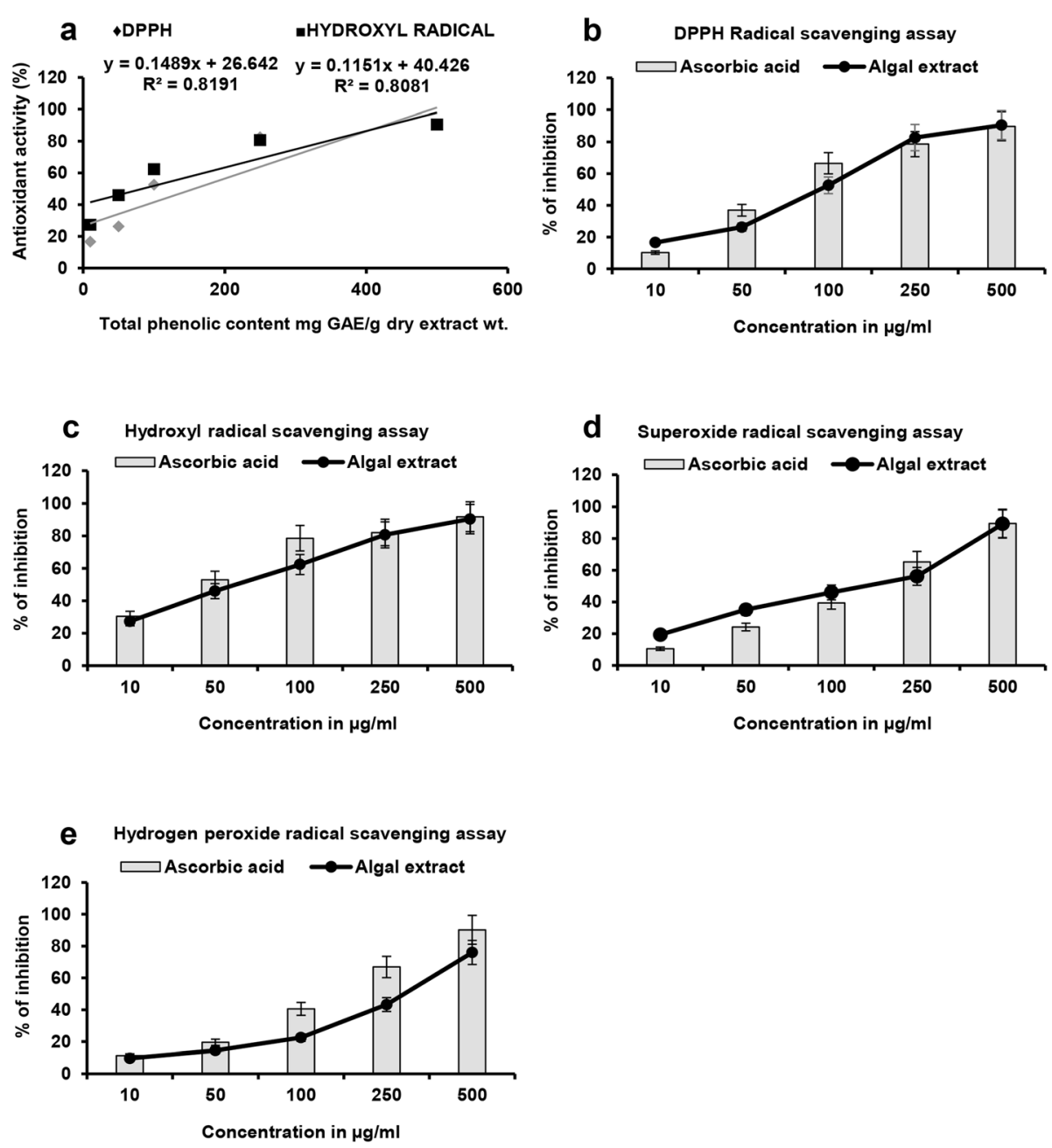

Fig. 2 Correlations between antioxidant capacity and total phenols of $C$. vulgaris extract (a). Different radical scavenging activity of methanol extract of the C. vulgaris such as DPPH radical scavenging activity (b), hydroxyl radical scavenging activity (c), superoxide radical scavenging activity (d), and hydrogen peroxide radical scavenging activity (e)

$50 \mu \mathrm{g} / \mathrm{ml}: 4.25,250 \mu \mathrm{g} / \mathrm{ml}: 3.39,500 \mu \mathrm{g} / \mathrm{ml}: 2.3)$ represented in $\mu \mathrm{mol} / \mathrm{mg}$ protein (Fig. 3e).

Drug synergism of methanolic extract of $C$. vulgaris in combination with norfloxacin and ciprofloxacin exert enhanced anti-bacterial potency against $E$. coli

To evaluate the enhanced anti-bacterial activity with drug synergism of methanolic extract of $\mathrm{C}$. vulgaris with norfloxacin and ciprofloxacin, we evaluated the $\mathrm{cfu} / \mathrm{ml}$ and $\%$ of cell viability in $E$. coli. In combination with

Table 3 Total phenolic, flavonoid, and antioxidant activity of $C$. vulgaris

\begin{tabular}{ll}
\hline Parameters & Extract \\
\hline Total phenolic content (mg of GAE/g) & $45 \pm 0.06$ \\
Total flavonoid content (mg of RUE/g) & $470 \pm 0.25$ \\
Total antioxidant activity (mg of AAE/g) & $411 \pm 0.39$ \\
\hline
\end{tabular}

norfloxacin, the $\mathrm{cfu} / \mathrm{ml}$ was estimated to be $4.969 \times 10^{7}$ as compared to norfloxacin with a value of $7.303 \times 10^{7}$ $\mathrm{cfu} / \mathrm{ml}$ (Fig. 4a). Similarly, a concurrent reduction of bacterial cell viability was observed in combination with norfloxacin $33.13 \%$ as compared to norfloxacin alone 48.69 \% (Fig. 4b). Similarly, in combination with ciprofloxacin, the $\mathrm{cfu} / \mathrm{ml}$ was estimated to be $4.0 \times 10^{7}$ as compared to ciprofloxacin with a value of $6.829 \times 10^{7}$ $\mathrm{cfu} / \mathrm{ml}$ (Fig. 4c). Similarly, a concurrent reduction of bacterial cell viability was observed in combination with ciprofloxacin $26.69 \%$ as compared to ciprofloxacin alone 45.53\% (Fig. 4d).

\section{Discussion}

Currently, the potential phytochemicals are given greater attention for the formulation of new pharmaceuticals for possible therapeutic use. These phytochemicals are usually categorized into primary metabolites such as 
Table $4 I_{50}$ Values of free radical scavenging activities of the methanol extracts of $C$. vulgaris

\begin{tabular}{lll}
\hline Parameters & $\mathrm{IC}$ 50 value $(\mu \mathrm{g} / \mathrm{ml})$ & Chlorella sp. \\
\cline { 2 - 3 } & Ascorbic acid & $2.82 \pm 0.30$ \\
\hline DPPH scavenging assay & $2.68 \pm 0.29$ & $2.30 \pm 0.25$ \\
Hydroxyl radical scavenging assay & $1.87 \pm 0.16$ & $3.24 \pm 0.32$ \\
Hydrogen peroxide Radical scavenging assay & $3.21 \pm 0.38$ & $3.15 \pm 0.02$ \\
Superoxide radical scavenging assay & $3.22 \pm 0.03$ & \\
\hline
\end{tabular}

carbohydrates, proteins, lipid, nucleic acid, various pigments, and secondary metabolites such as alkaloids, glycosides, flavonoids, phenols, saponins, tannins, coumarins, and terpenoids. The major of these bioactive compounds were reported in various algal genera [26, 42]. Phenolic and flavonoid compounds of the plant and algae displayed several biological activities and elicited substantial antioxidant activity [26, 29, 42, 43]. The present study on C. vulgaris demonstrated the presence of active phytochemicals and exhibited antioxidant properties due to the presence of phenolics, flavonoids, and tannins in the line of findings of the earlier report [42]. The present study results were displayed an abundance of phenolic constituents as well as an increase of free radical scavenging activity in the crude extracts. Consequently, the presence of phenolics was an authoritative antioxidant agent responsible for neutralizing free radicals by contributing hydrogen atoms to free radicals and
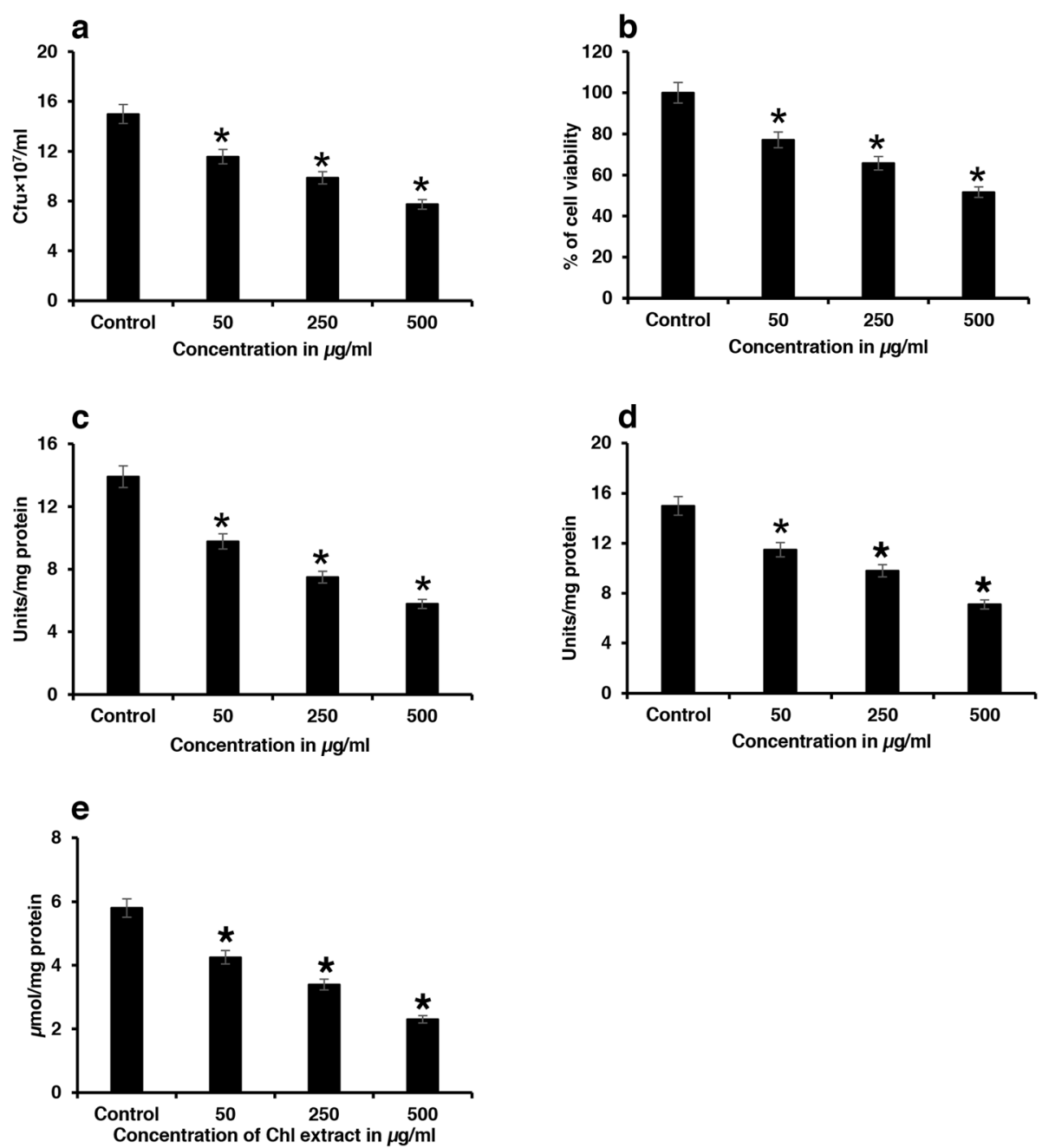

Fig. 3 The cfu/ml count in dose-dependent methanolic extract of C. vulgaris (a), \% of cell viability (b). The SOD (c), CAT (d), and GSH (e) activity post-dose-dependent treatment of methanolic extract of the C. vulgaris 

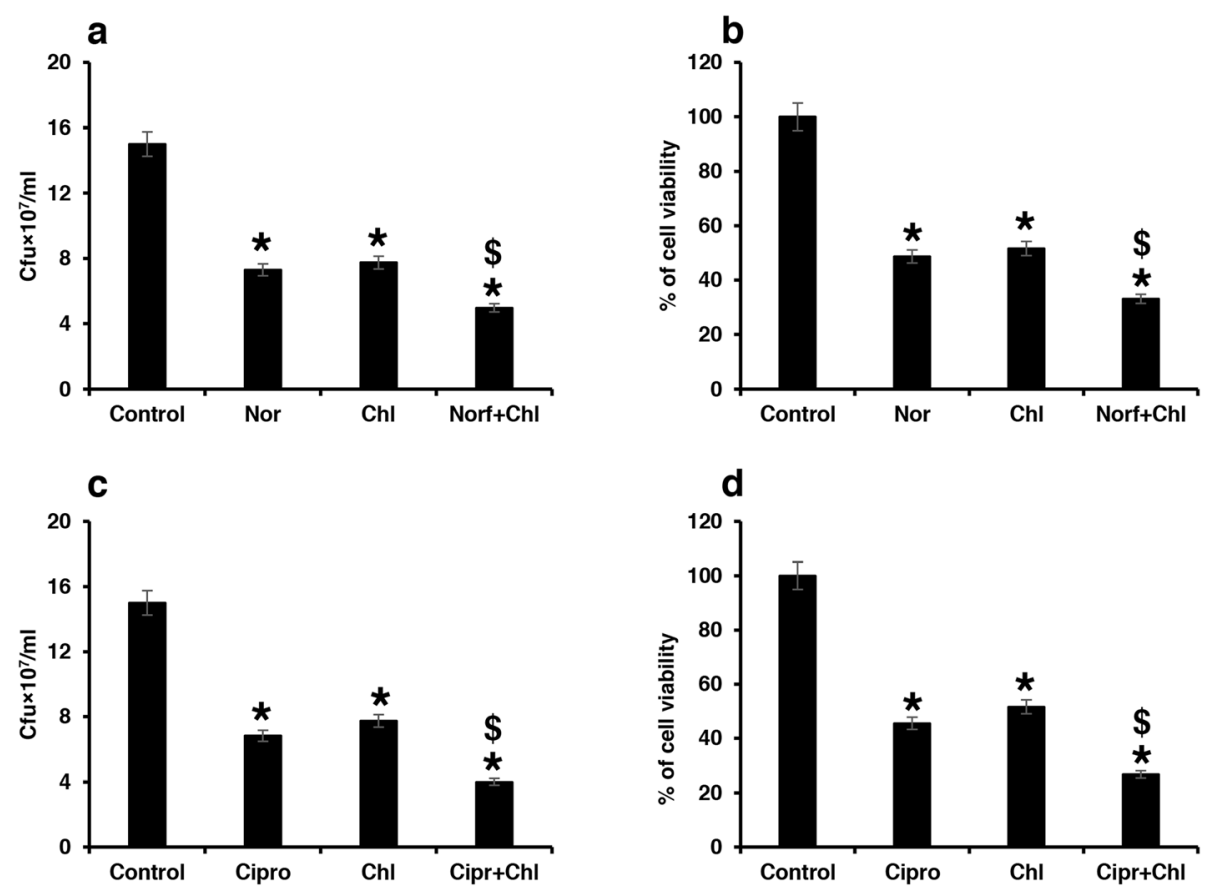

Fig. 4 The cfu/ml count (a) and \% of cell viability (b) in the synergistic effect of methanol extract of the C. vulgaris with norfloxacin. A similar cfu/ $\mathrm{ml}$ count $(\mathbf{c})$ and \% of cell viability (d) in the synergistic effect of methanol extract of the $C$. vulgaris with ciprofloxacin

reducing the reactive oxygen species. So, our findings in line with the previous report that phenolics are scavenging reactive oxygen species and reduce the production of singlet oxygen species and ROS [44]. The phenolic content of Isochrysis galbana Parke, Tetraselmis chuii Butcher, and Dunaliella salina (Dunal) Teodoresco were evaluated with maximum content signifying $17.798 \mathrm{mg}$ $\mathrm{GAE} \mathrm{g}^{-1}$ [45]. Further, Euglena cantabrica E.G. Pringsheim displayed the maximum phenolic compounds 5.87 mg GAE $\mathrm{g}^{-1}$ and $2.97 \mathrm{mg}$ protocatechuic acids $\mathrm{g}^{-1}$ [46]. The phenolic content was evaluated in Chlorella sp. 43 $\pm 0.05 \mathrm{mg}$ of GAE g $\mathrm{g}^{-1}$ [26]. The present study signified with high TPC value ( $\left.45 \pm 0.06 \mathrm{mg} \mathrm{GAE} \mathrm{g}^{-1}\right)$ compared to the previous report to date in Chlorella sp. The TFC value in microalgae Euglena tuba was evaluated to be $100.78 \pm 2.114 \mathrm{mg} \mathrm{g}^{-1}$ extract quercetin equivalent [42] and flavonoids contents in Chlorella sp. was $501 \pm 0.88$ $\mathrm{mg}$ rutin $\mathrm{g}^{-1}$ in our previous report. However, interestingly in the current investigation elicited profusely, a less TFC, i.e., $470 \pm 0.25 \mathrm{mg}^{\mathrm{RUE}} \mathrm{g}^{-1}$ compared to the previous report [26].

Different literature indicated a linear correlation between TPC and TFC with antioxidant activity [47]. Hence, various methods were used to evaluate the antioxidant activity in this study. The total antioxidant capacity (TAC) was measured based on the reduction of Mo (VI) to Mo (V) followed by later production of green phosphate Mo (V) compound in an acidic $\mathrm{pH}$. The TAC of methanolic crude extract was elicited maximum in this strain C. vulgaris due to the presence of maximum TPC and TFC. The present study was in support of the published reports [26]. The UV-visible spectrophotometric spectral range from 200 to $800 \mathrm{~nm}$, and resultant absorbance indicates the presence of phenolics compounds [48]. Therefore, the UV-visible spectroscopic spectral scan and FT-IR spectroscopy spectral scan was performed to cross-check the presence of phenolics and flavonoids in the $C$. vulgaris methanolic extract. Our findings exhibited the absorbance at various $\mathrm{nm}$ with signified spectral peak both in UV-visible spectroscopy and FT-IR spectroscopy displayed the presence of different functional groups of the compounds in the extract (Fig. 1a, b). The UV-visible spectral peak indicated the presence of phenolics and flavonoids, FT-IR spectral peak indicated the presence of different bioactive phytochemicals and their functional groups present (Table 2). Our present study results were in line with findings of a previous study in Padina pavonica (Linnaeus) extract and seaweed Sargassum wightii Greville ex J.Agardh extract [49]. In addition, the investigated results were also supported by spectral peaks obtained in seeds and flower extract that indicated the presence of alkaloids, flavonoids, and glycoside [27]. All these bioactive antioxidant agents hold high prevalence in therapeutic purposes [50]. So, in the present study, the microalga Chlorella vulgaris Beyerinck [Beijerinck] was attributed strong antioxidant activities due to the presence of an abundance of phenolic, flavonoids, and other active 
phytochemicals which were in the line of findings of Chlorella strains antioxidant activities [51].

Furthermore, several biochemical assays have been employed to evaluate the free radicals scavenging capacity of antioxidants. Thus, the DPPH assay was used to estimate the competence of free radicals scavenging activity of active antioxidants present in the algal extracts. The presence of antioxidants in the algal extract reduces the deep violet color DPPH solution to fade yellow color by accepting an electron or hydrogen radical and convert to a diamagnetic stable molecule. Besides the $\mathrm{IC}_{50}$ values of the DPPH radical scavenging activity of the methanol extract against the standard ascorbic acid displayed significant inhibition as an increase in concentration confirmed the strong antioxidant activity. This finding is in line with the previous reports [50, 52-54]. The byproducts of immune action hydroxyl radicals can occasionally produce in the cell and are short-lived. However, these radicals are extremely reactive and can spoil various important macromolecules in the cells and are becoming dangerous to human health. Thus, the neutralizing redundant hydroxyl radical in the cell is essential. Hence, the hydroxyl radical scavenging activity of the algal extract was examined, and the result displayed an increase in inhibition with an increase of algal concentration and it was validated by $\mathrm{IC}_{50}$ values of the strain. The activity of hydroxyl ion scavenging activity perceived in this was in the line with the previous report $[26,29,42,43] . \mathrm{H}_{2} \mathrm{O}_{2}$ is usually a fragile oxidizing agent, which can cross biological membranes and engage in the production of hydroxyl radicals. Further, this property has a major role to instigate cytotoxicity effects. Thus, diminishing $\mathrm{H}_{2} \mathrm{O}_{2}$ in the cells is very important for the protection of living systems [55]. Hence, the scavenging activities of the algal extract in the present study were examined and the scavenging activities displayed in a concentration-dependent manner compared to standard ascorbic acid. It was also observed from their respective $\mathrm{IC}_{50}$ values scavenging of $\mathrm{H}_{2} \mathrm{O}_{2}$ by the algal extract with ascorbic acid. It can be attributed to their phenolics, which can give electrons to $\mathrm{H}_{2} \mathrm{O}_{2}$ and neutralizing it to water [56]. Superoxide radical is produced by autooxidation and non-enzymatic electron transfers to reduce molecular oxygen in the cell. This is pretty toxic, causes oxidative upset in the cells, and may play a role in many oxidative diseases. The antioxidant properties of flavonoids are effective in scavenging the superoxide anion radicals [57]. The superoxide radical scavenging activity of the methanolic extract was measured by decreasing absorbance reflecting the consumption of superoxide radicals $[58,59]$. From our result, the $\mathrm{IC}_{50}$ values of superoxide radical scavenging assay indicated that the extract possessed strong superoxide radical scavenging activity than the standard ascorbic acid. Our investigations are in the support of published reports $[42,53]$.

The anti-microbial compounds from algae include structurally devised phytoactive compounds that include phenolic and flavonoid groups. This study exhibited that methanolic extract of C. vulgaris was more effective against $E$. coli with the subsequent reduction in $\mathrm{cfu} / \mathrm{ml}$ and $\%$ of bacterial cell viability. The results of the present investigation were well supported with the study of ethanolic extract of Nostoc calcicola exhibiting effective anti-bacterial activity against E. coli and Staphylococcus aureus [60]. The reduction in cell viability is possible due to the onset of oxidative imbalance post-drug treatment. After drug treatment, a subsequent reduction in cell viability was evident due to downregulation of SOD, CAT, and GSH activity which further lead to ROSmediated cell death. The result of the current finding is in the line of previous study Scott et al. and Schwartz et al. [40, 41]. In the current therapeutic scenario, drug synergism has been implicated as a possible strategy for enhanced therapeutic efficacy. Interestingly, the results of the present investigation have demonstrated that methanolic extract of $C$. vulgaris in combination with norfloxacin and ciprofloxacin exhibited a reduction in $\mathrm{cfu} / \mathrm{ml}$ and cell viability. The finding of this study is well supported by the previous investigation of Coronarin D in combination with antibiotics exhibit enhanced antimicrobial activity against E. coli [61].

\section{Conclusion}

Microalgal bioactive compounds act as potent scavengers of intracellular free radicals owing to the presence of phenolic and flavonoids constituents. The present study uncovered the effectiveness of methanolic extract of Chlorella vulgaris as a potent antioxidant in vitro. The effective reduction of the DPPH, hydrogen peroxide, hydroxyl, and superoxide radicals established the methanolic extract of Chlorella vulgaris as a potent ROS scavenger than standard ascorbic acid. Moreover, it also regulates bacterial diseases via the downregulation of antioxidant enzymes. In addition, it displays enhanced anti-bacterial efficacy in combination with known antibiotics. Further investigation for designing and developing potential ROS scavengers from this species will ensure the production of effective synthetic pharmacophores with enhanced bioavailability and greater efficacy in therapeutic implementations.

\section{Abbreviations}

DPPH: 1,1-Diphenyl-2-picrylhydrazyl; TPC: Total phenol content; TFC: Total flavonoid content; TAA: Total antioxidant activity; SOD: Superoxide dismutase; CAT: Catalase; GSH: Reduced glutathione; Cfu: Colony-forming unit; E.coli: Escherichia coli; C. vulgaris: Chlorella vulgaris; FT-IR: Fourier transform infrared; Nor: Norfloxacin; Cipro: Ciprofloxacin 


\section{Acknowledgements}

We are thankful to Head, Department of Chemistry, and Berhampur University, for providing FT-IR spectroscopy. The authors are also thankful to Berhampur University for providing the necessary facilities.

\section{Plant authentication}

The pure strain Chlorella vulgaris was collected from Sonapur on the sea, Ganjam, Odisha, and isolated by Biswajita Pradhan, authenticated by Dr. Mrutyunjay Jena. The strain was assigned with strain no. BUACC25 and submitted the algal culture collection of Berhampur University.

\section{Authors' contributions}

$\mathrm{BP}, \mathrm{SP}$, and $\mathrm{MJ}$ designed the work. $\mathrm{BP}, \mathrm{SP}$, and $\mathrm{RN}$ have done the experimental work. BP, SP, SRD, and CB have done data interpretation and graphics. BP, SP, and MJ have drafted the work or substantively revised and proof reading. All authors read and approved the final manuscript.

\section{Funding}

The authors are thankful to MoEF \& CC, Govt. of India and S \& T Department, Govt. of Odisha, to carry out this piece of research work.

\section{Availability of data and materials}

All data and material are available upon request.

\section{Ethics approval and consent to participate}

Not applicable.

\section{Consent for publication}

Not applicable.

\section{Competing interests}

The authors declare that they have no competing interests.

Received: 22 September 2020 Accepted: 28 December 2020 Published online: 11 January 2021

\section{References}

1. Maharana S, Pradhan B, Jena M, Misra MK (2019) Diversity of phytoplankton in Chilika Lagoon, Odisha, India. Environ Ecol 37(3):737-746

2. Malve $H$ (2016) Exploring the ocean for new drug developments: marine pharmacology. J Pharm Bioallied Sci 8(2):83-91. https://doi.org/10.4103/ 0975-7406.171700

3. Patra S, Praharaj PP, Panigrahi DP, Panda B, Bhol CS, Mahapatra KK, Mishra SR, Behera BP, Jena M, Sethi G, Patil S, Patra SK, Bhutia SK (2020) Bioactive compounds from marine invertebrates as potent anticancer drugs: the possible pharmacophores modulating cell death pathways. Mol Biol Rep. https://doi.org/10.1007/s1 1033-020-05709-8

4. Wells ML, Potin P, Craigie JS, Raven JA, Merchant SS, Helliwell KE, Smith AG, Camire ME, Brawley SH (2017) Algae as nutritional and functional food sources: revisiting our understanding. J Appl Phycol 29(2):949-982. https:// doi.org/10.1007/s10811-016-0974-5

5. Pradhan B, Patra S, Nayak R, Behera C, Dash SR, Nayak S, Sahu BB, Bhutia SK, Jena M (2020) Multifunctional role of fucoidan, sulfated polysaccharides in human health and disease: A journey under the sea in pursuit of potent therapeutic agents. Int J Biol Macromol. https://doi.org/10.1016/j.jibiomac. 2020.09.019

6. Gam DH, Yi Kim S, Kim JW (2020) Optimization of ultrasound-assisted extraction condition for phenolic compounds, antioxidant activity, and epigallocatechin gallate in lipid-extracted microalgae. Molecules 25(3). https://doi.org/10.3390/molecules25030454

7. Stabili L, Acquaviva Ml, Angile F, Cavallo RA, Cecere E, Del Coco L, Fanizzi FP, Gerardi C, Narracci M, Petrocelli A (2019) Screening of chaetomorpha linum lipidic extract as a new potential source of bioactive compounds. Mar Drugs 17(6). https://doi.org/10.3390/md17060313

8. Olasehinde TA, Olaniran AO, Okoh Al (2019) Phenolic composition, antioxidant activity, anticholinesterase potential and modulatory effects of aqueous extracts of some seaweeds on beta-amyloid aggregation and disaggregation. Pharm Biol 57(1):460-469. https:/doi.org/10.1080/13880209.2019.1634741

9. Narasimhan MK, Pavithra SK, Krishnan V, Chandrasekaran M (2013) In vitro analysis of antioxidant, antimicrobial and antiproliferative activity of enteromorpha antenna, enteromorpha linza and gracilaria corticata extracts.
Jundishapur J Nat Pharm Prod 8(4):151-159. https://doi.org/10.17795/jjnpp11277

10. Chakraborty K, Maneesh A, Makkar F (2017) Antioxidant activity of brown seaweeds. J Aquatic Food Prod Technol 26(4):406-419. https://doi.org/10. 1080/10498850.2016.1201711

11. Lauritano C, Ferrante MI (2019) Marine natural products from microalgae: an -omics overview. 17(5). doi:https://doi.org/10.3390/md17050269

12. Pradhan B, Patra S, Dash SR, Maharana S, Behera C, Jena M (2020) Antioxidant responses against aluminum metal stress in Geitlerinema amphibium. SN Appl Sci 2(5):800. https://doi.org/10.1007/s42452-020-2599-1

13. Rastogi RP, Singh SP, Hader DP, Sinha RP (2010) Detection of reactive oxygen species (ROS) by the oxidant-sensing probe 2',7'dichlorodihydrofluorescein diacetate in the cyanobacterium Anabaena variabilis PCC 7937. Biochem Biophys Res Commun 397(3):603-607. https:// doi.org/10.1016/j.bbrc.2010.06.006

14. Pisoschi AM, Pop A (2015) The role of antioxidants in the chemistry of oxidative stress: A review. Eur J Med Chem 97:55-74. https://doi.org/10. 1016/j.ejmech.2015.04.040

15. Nunomura A, Castellani RJ, Zhu X, Moreira PI, Perry G, Smith MA (2006) Involvement of oxidative stress in Alzheimer disease. J Neuropathol Exp Neurol 65(7):631-641. https://doi.org/10.1097/01.jnen.0000228136.58062.bf

16. Leopold JA (2015) Antioxidants and coronary artery disease: from pathophysiology to preventive therapy. Coron Artery Dis 26(2):176-183. https://doi.org/10.1097/mca.0000000000000187

17. Kasote DM, Katyare SS, Hegde MV, Bae H (2015) Significance of antioxidant potential of plants and its relevance to therapeutic applications. Int J Biol Sci 11(8):982-991. https://doi.org/10.7150/ijbs.12096

18. Sansone C, Brunet C (2019) Promises and challenges of microalgal antioxidant production. Antioxidants 8(7). https://doi.org/10.3390/ antiox8070199

19. Poprac P, Jomova K, Simunkova M, Kollar V, Rhodes CJ, Valko M (2017) Targeting free radicals in oxidative stress-related human diseases. Trends Pharmacol Sci 38(7):592-607. https://doi.org/10.1016/j.tips.2017.04.005

20. Martins N, Barros L, Ferreira IC (2016) In vivo antioxidant activity of phenolic compounds: Facts and gaps. Trends Food Sci Technol 48:1-12

21. Xu DP, Li Y, Meng X, Zhou T, Zhou Y, Zheng J, Zhang JJ, Li HB (2017) Natural antioxidants in foods and medicinal plants: extraction, assessment and resources. Int J Mol Sci 18(1). https://doi.org/10.3390/ijms18010096

22. Tavakoli J, Brewer S, Jelyani A, Estakhr P (2017) Oxidative stability of olive oil during thermal process: effect of Pistacia khinjuk fruit oil. Int J Food Prop 20 doi:https://doi.org/10.1080/10942912.2017.1285787

23. Younes G, Rasoul-Amini S, Morowvat MH (2011) Algae for the production of SCP. Bioprocess Sci Technol:Nova Science Publishers, Inc: 163-184

24. Lin PY, Tsai CT, Chuang WL, Chao YH, Pan IH, Chen YK, Lin CC, Wang BY (2017) Chlorella sorokiniana induces mitochondrial-mediated apoptosis in human non-small cell lung cancer cells and inhibits xenograft tumor growth in vivo. BMC Complement Altern Med 17(1):88. https://doi.org/10. 1186/s12906-017-1611-9

25. Syed S, Arasu A, Ponnuswamy I (2015) The uses of Chlorella vulgaris as antimicrobial agent and as a diet: the presence of bio-active compounds which caters the vitamins, minerals in general. Int J Bio Sci Bio Technol 7(1): 185-190

26. Pradhan B, Baral S, Patra S, Behera C, Nayak R, MubarakAli D, Jena M (2020) Delineation of gamma irradiation (60Co) induced oxidative stress by decrypting antioxidants and biochemical responses of microalga, Chlorella sp. Biocatalys Agric Biotechnol 25:101595. https://doi.org/10.1016/j.bcab.2020.101595

27. Sofowora A (1996) Research on medicinal plants and traditional medicine in Africa. J Altern Complement Med 2(3):365-372. https://doi.org/10.1089/acm. 1996.2.365

28. Mohanty S, Pradhan B, Patra S, Behera C, Nayak R, Jena M (2020) Screening for nutritive bioactive compounds in some algal strains isolated from coastal Odisha. J Adv Plant Sci 10(2):1-8

29. Patra S, Panda PK, Naik PP, Panigrahi DP, Praharaj PP, Bhol CS, Mahapatra KK, Padhi P, Jena M, Patil S (2020) Terminalia bellirica extract induces anticancer activity through modulation of apoptosis and autophagy in oral squamous cell carcinoma. Food Chem Toxicol 136:111073

30. Patra S, Bhol CS, Panigrahi DP, Praharaj PP, Pradhan B, Jena M, Bhutia SK (2020) Gamma irradiation promotes chemo-sensitization potential of gallic acid through attenuation of autophagic flux to trigger apoptosis in an NRF2 inactivation signalling pathway. Free Radical Biol Med 160:111-124. https:// doi.org/10.1016/j.freeradbiomed.2020.06.022 
31. Quettier-Deleu C, Gressier B, Vasseur J, Dine T, Brunet C, Luyckx M, Cazin M, Cazin JC, Bailleul F, Trotin F (2000) Phenolic compounds and antioxidant activities of buckwheat (Fagopyrum esculentum Moench) hulls and flour. J Ethnopharmacol 72(1-2):35-42. https://doi.org/10.1016/s03788741(00)00196-3

32. Prieto P, Pineda M, Aguilar M (1999) Spectrophotometric quantitation of antioxidant capacity through the formation of a phosphomolybdenum complex: specific application to the determination of vitamin E. Anal Biochem 269(2):337-341. https://doi.org/10.1006/abio.1999.4019

33. Pradhan B, Patra S, Maharana S, Behera C, Dash SR, Jena M (2020) Demarcating antioxidant response against aluminum induced oxidative stress in Westiellopsis prolifica Janet 1941.1-14. Int J Phytoremediation. https://doi.org/10.1080/15226514.2020.1807906

34. Pradhan B, Patra S, Behera C, Nayak R, Patil S, Bhutia SK, Jena M (2020) Enteromorpha compressa extract induces anticancer activity through apoptosis and autophagy in oral cancer. https://doi.org/10.1007/s11033-02006010-4

35. Liu F, Ooi VE, Chang ST (1997) Free radical scavenging activities of mushroom polysaccharide extracts. Life Sci 60(10):763-771. https://doi.org/ 10.1016/s0024-3205(97)00004-0

36. Karley D, Shukla SK, Rao TS (2018) Isolation and characterization of culturable bacteria present in the spent nuclear fuel pool water. Environ Sci Pollut Res Int 25(21):20518-20526. https://doi.org/10.1007/s11356-017-03765

37. Sieuwerts S, de Bok FA, Mols E, de Vos WM, Vlieg JE (2008) A simple and fast method for determining colony forming units. Lett Appl Microbiol 47(4):275-278. https://doi.org/10.1111/j.1472-765X.2008.02417.x

38. Ren Y, Chow LM, Leung WW (2013) Cell culture using centrifugal microfluidic platform with demonstration on Pichia pastoris. Biomed Microdev 15(2):321-337. https://doi.org/10.1007/s10544-012-9735-7

39. Bhaduri S, Demchick PH (1983) Simple and rapid method for disruption of bacteria for protein studies. Appl Environ Microbiol 46(4):941-943. https:// doi.org/10.1128/AEM.46.4.941-943.1983

40. Scott MD, Meshnick SR, Eaton JW (1987) Superoxide dismutase-rich bacteria. Paradoxical increase in oxidant toxicity. J Biol Chem 262(8):3640-3645

41. Schwartz CE, Krall J, Norton L, McKay K, Kay D, Lynch RE (1983) Catalase and superoxide dismutase in Escherichia coli. J Biol Chem 258(10):6277-6281

42. Chaudhuri D, Ghate NB, Deb S, Panja S, Sarkar R, Rout J, Mandal N (2014) Assessment of the phytochemical constituents and antioxidant activity of a bloom forming microalgae Euglena tuba. Biol Res 47(1):24

43. Behera SK (2018) Phytochemical screening and antioxidant properties of methanolic extract of root of Asparagus racemosus Linn. Int J Food Prop 21(1):2681-2688. https://doi.org/10.1080/10942912.2018.1560310

44. Balboa EM, Conde E, Moure A, Falqué E, Domínguez H (2013) In vitro antioxidant properties of crude extracts and compounds from brown algae. Food Chem 138(2-3):1764-1785

45. Widowati I, Zainuri M, Kusumaningrum HP, Susilowati R, Hardivillier $Y$, Leignel V, Bourgougnon N, Mouget JL (2017) Antioxidant activity of three microalgae Dunaliella salina, Tetraselmis chuii and Isochrysis galbana clone Tahiti. In: IOP Conference Series: Earth and Environmental Science, vol 1. IOP Publishing, Bristol, England, p 012067

46. Jerez-Martel I, García-Poza S, Rodríguez-Martel G, Rico M, Afonso-Olivares C, Gómez-Pinchetti JL (2017) Phenolic profile and antioxidant activity of crude extracts from microalgae and cyanobacteria strains. J Food Qual 2017:1-8.

47. Choudhary RK, Swarnkar PL (2011) Antioxidant activity of phenolic and flavonoid compounds in some medicinal plants of India. Nat Prod Res 25(11):1101-1109. https://doi.org/10.1080/14786419.2010.498372

48. Boulet J, Ducasse M-A, Cheynier V (2017) Ultraviolet spectroscopy study of phenolic substances and other major compounds in red wines: relationship between astringency and the concentration of phenolic substances: UV spectroscopy of red wine components. Aust J Grape Wine Res 23. https:// doi.org/10.1111/ajgw.12265

49. Rajeswari R, Jeyaprakash K (2019) Bioactive potential analysis of brown seaweed Sargassum wightii using UV-VIS and FT-IR. J Drug Deliv Ther 9: 150-153. https://doi.org/10.22270/jddt.v9i1.2199

50. Gülçin I, Huyut Z, Elmastaş M, Aboul-Enein HY (2010) Radical scavenging and antioxidant activity of tannic acid. Arab J Chem 3(1):43-53

51. Chatzikonstantinou M, Kalliampakou A, Gatzogia M, Flemetakis E, Katharios P, Labrou NE (2017) Comparative analyses and evaluation of the cosmeceutical potential of selected Chlorella strains. J Appl Phycol 29(1): 179-188
52. Ozcelik B, Lee J, Min D (2003) Effects of light, oxygen, and pH on the absorbance of 2, 2-diphenyl-1-picrylhydrazyl. J Food Sci 68(2):487-490

53. Chen C, You L-J, Abbasi AM, Fu X, Liu RH (2015) Optimization for ultrasound extraction of polysaccharides from mulberry fruits with antioxidant and hyperglycemic activity in vitro. Carbohydr Polym 130:122-132

54. Soare JR, Dinis TC, Cunha AP, Almeida L (1997) Antioxidant activities of some extracts of Thymus zygis. Free Radical Res 26(5):469-478

55. Wijk RV, Wijk E, Van P, Wiegant FA, Ives J (2008) Free radicals and low-level photon emission in human pathogenesis: state of the art

56. Ebrahimzadeh M, Nabavi S, Nabavi S (2009) Antioxidant activities of methanol extract of Sambucus ebulus L. flower. Pakistan J Biol Sci 12(5):447

57. Yen GC, Duh PD (1994) Scavenging effect of methanolic extracts of peanut hulls on free-radical and active-oxygen species. J Agric Food Chem 42(3): 629-632

58. Gülçin I, Topal F, Sarikaya SBÖ, Bursal E, Bilsel G, Gören AC (2011) Polyphenol contents and antioxidant properties of medlar (Mespilus germanica L). Rec Nat Prod 5(3):158

59. Parejo I, Viladomat F, Bastida J, Rosas-Romero A, Flerlage N, Burillo J, Codina C (2002) Comparison between the radical scavenging activity and antioxidant activity of six distilled and nondistilled Mediterranean herbs and aromatic plants. J Agric Food Chem 50(23):6882-6890

60. Agrawal MK (2016) Antimicrobial activity of Nostoc calcicola (Cyanobacteria) isolated from central India against human pathogens. Asian J Pharm 10(04): 554-559.

61. Reuk-ngam N, Chimnoi N, Khunnawutmanotham N (2014) Antimicrobial activity of coronarin $\mathrm{D}$ and its synergistic potential with antibiotics. BioMed Res Int 2014:581985. https://doi.org/10.1155/2014/581985

\section{Publisher's Note}

Springer Nature remains neutral with regard to jurisdictional claims in published maps and institutional affiliations.

\section{Submit your manuscript to a SpringerOpen ${ }^{\circ}$ journal and benefit from:}

- Convenient online submission

- Rigorous peer review

- Open access: articles freely available online

- High visibility within the field

- Retaining the copyright to your article

Submit your next manuscript at $>$ springeropen.com 